\title{
Comment on Ernest et al. Programmable Thermal Dissociation of Reactive Gaseous Mercury, A Potential Approach to Chemical Speciation: Results from a Field Study. Atmosphere 2014, $5,575-596$
}

\author{
Keith Schofield \\ Tel.: +1-805-966-6589; Fax: +1-805-965-9953 \\ Academic Editor: Robert W. Talbot \\ Received: 19 August 2016; Accepted: 31 August 2016; Published: 19 September 2016
}

Materials Research Laboratory, University of California, Santa Barbara, CA 93106, USA; KSHome@ucsb.edu;

The authors of this paper utilized a so-called "programmable thermal dissociation method" to monitor $\mathrm{HgCl}_{2}$ emitted from a coal-fired Florida combustion plant. By comparison, they did confirm that the emitted mercury compound was in fact the dichloride, which is in fact the only such plausible molecule for mercury. However, the subtle implications in the paper that the $\mathrm{HgCl}_{2}(\mathrm{~g})$ molecule is not thermally stable and can readily dissociate in the gas phase at temperatures below $300{ }^{\circ} \mathrm{C}$ is not consistent with a very broad spectrum of chemical information and clearly can be misleading and incorrect if not more fully explained.

Unlike elemental mercury, its dichloride is known as a corrosive sublimate and it is soluble in water. Its heat of formation and heat of vaporization are well known, providing a gas-phase heat of formation that indicates an atomization energy $\mathrm{D}_{0 \text {,Atomization }}\left(\mathrm{HgCl}_{2}\right)_{\mathrm{g}}=445 \pm 5 \mathrm{~kJ} \cdot \mathrm{mol}^{-1}[1,2]$, supported also by theory [3]. The monohalide, $\mathrm{HgCl}(\mathrm{g})$, is well characterized and known to be very weakly bound, with $\mathrm{D}_{0}(\mathrm{HgCl})=96 \pm 8 \mathrm{~kJ} \cdot \mathrm{mol}^{-1}$ (experimentally) $[4,5]$ and $94 \mathrm{~kJ} \cdot \mathrm{mol}^{-1}$ (theoretically) [3,6,7]. Coupling these values implies the $\mathrm{ClHg}-\mathrm{Cl}$ bond in $\mathrm{HgCl}_{2}(\mathrm{~g})$ has a bond strength of about $350 \mathrm{~kJ} \cdot \mathrm{mol}^{-1}$. This is a significant strength and clearly indicates the unequal strengths of the two bonds. Its stability is the reason, in chemical equilibrium calculations describing combustion, why it is predicted that elemental $\mathrm{Hg}$ should be negligible and $\mathrm{HgCl}_{2}(\mathrm{~g})$ dominant [8]. The fact that it is not is due to the kinetic and time constraints on the formation mechanisms converting $\mathrm{Hg}$ to $\mathrm{HgCl}_{2}$. Nevertheless, the thermodynamic calculations illustrate its bond strength and that it should be thermally stable below $500{ }^{\circ} \mathrm{C}$, above which it does begin to thermally dissociate or be hydrolyzed by any gaseous water present. $\mathrm{HgCl}_{2}(\mathrm{~s})$ is very volatile and its vapor pressure is well established $[2,9,10]$. This increases rapidly in the $150-250{ }^{\circ} \mathrm{C}$ range $\left(3 \times 10^{-3} \mathrm{~atm}\right.$., $\left.150{ }^{\circ} \mathrm{C} ; 0.1,228{ }^{\circ} \mathrm{C} ; 0.2,246{ }^{\circ} \mathrm{C}\right)$, with a boiling point of about $300{ }^{\circ} \mathrm{C}$. Thermogravimetric measurements for $\mathrm{HgCl}_{2}$ clearly indicate this rapid sublimation [11], and an attached atomic absorption analyzer confirmed the molecular nature of the vaporization [12]. No evidence was indicated for the presence of free $\mathrm{Hg}$ atoms while the mass decreased. The confusion has arisen from mercury's ability under certain conditions to release atomic mercury in nature from its molecules not only from oceanic sources but also from vegetation and soils $[13,14]$. This also has been apparent when $\mathrm{HgCl}_{2}$ is absorbed into mixtures such as quartz, pyrex or ceramic wool, or activated charcoal [15], or may happen from the gypsum produced from combustor flue gas desulfurizers [16]. Although studied for many years, the mechanism for this chemical reduction and release still remains unknown $[17,18]$.

In relation to coal combustion, this laboratory has monitored the induced conversion of $\mathrm{Hg}(\mathrm{g})$ to $\mathrm{HgCl}_{2}(\mathrm{~g})$ on passing coal-fired flue gases through a non-catalytic honeycomb carbon-steel metal insert held at temperatures in the region of $250{ }^{\circ} \mathrm{C}$. This has now been confirmed in two coal-fired 
pilot plant tests in which the mercury speciation and total mercury were monitored entering and leaving the thermostated insert using Tekran monitors that measure atomic, molecular and total gaseous mercury [19]. This work has clearly indicated that $\mathrm{HgCl}_{2}(\mathrm{~g})$ can be heterogeneously formed in transit through the insert with conversions up to $>80 \%$. Rather than dissociation, only formation of gaseous $\mathrm{HgCl}_{2}$ was evident for a broad temperature range, so claims of its instability under combustion conditions at low temperatures are not correct. What is being observed in this presently published case possibly remains uncertain. As to the nature of collection on the uncoated tubular denuders and whether this is the same as coating them with a standard chemical remains uncertain. The fact that similar vaporization curves were noted for the test and calibration does appear to confirm the results. Used in a broader, more complex mix application, it might be more difficult to analyze.

Conflicts of Interest: The author declares no conflict of interest.

\section{References}

1. Knacke, O.; Kubaschewski, O.; Hesselmann, K. (Eds.) Thermochemical Properties of Inorganic Substances, 2nd ed.; Springer-Verlag: Berlin, Germany, 1991; Volumes 1 and 2, pp. 1-2412.

2. Barin, I.; Platzki, G. Thermochemical Data of Pure Substances, 3rd ed.; VCH Verlagsgesellschaft mbH: Weinheim, Germany, 1995; Volumes 1 and 2, pp. 1-1885.

3. Balabanov, N.B.; Peterson, K.A. Mercury and reactive halogens: The thermochemistry of $\mathrm{Hg}+\left\{\mathrm{Cl}_{2}, \mathrm{Br}_{2}\right.$, $\mathrm{BrCl}, \mathrm{ClO}$ and $\mathrm{BrO}$. J. Phys. Chem. A 2003, 107, 7465-7470. [CrossRef]

4. Wilcomb, B.E.; Bernstein, R.B. Dissociation energies of ground state $\mathrm{HgX}$ molecules $(\mathrm{X}=\mathrm{I}, \mathrm{Br}, \mathrm{Cl})$ from analysis of vibrational level spacings. J. Mol. Spectrosc. 1976, 62, 442-448. [CrossRef]

5. Linn, S.H.; Brom, J.M., Jr.; Tzeng, W.-B.; Ng, C.Y. Molecular beam photoionization study of $\mathrm{HgCl}_{2}$. J. Chem. Phys. 1983, 78, 37-45. [CrossRef]

6. Khalizov, A.F.; Viswanathan, B.; Larregaray, P.; Ariya, P.A. A theoretical study on the reaction of $\mathrm{Hg}$ with halogens: Atmospheric implications. J. Phys. Chem. A 2003, 107, 6360-6365. [CrossRef]

7. Shepler, B.C.; Balabanov, N.B.; Peterson, K.A. Ab initio thermochemistry involving heavy atoms: An investigation of the reactions $\mathrm{Hg}+\mathrm{IX}(\mathrm{X}=\mathrm{I}, \mathrm{Br}, \mathrm{Cl}$, O). J. Phys. Chem. A 2005, 109, 10363-10372. [CrossRef] [PubMed]

8. Frandsen, F.; Dam-Johansen, K.; Rasmussen, P. Trace elements from combustion and gasification of coal: An equilibrium approach. Prog. Energy Combust. Sci. 1994, 20, 115-138. [CrossRef]

9. Ruf, R.; Treadwell, W.D. The vapor pressure of mercuric chloride. Helv. Chim. Acta 1954, 37, 1941-1948. [CrossRef]

10. Bernard, L.; Awitor, K.O.; Badaud, J.P.; Bonnin, O.; Coupat, B.; Fournier, J.P.; Verdier, P. Determination of the vapor pressure of $\mathrm{HgCl}_{2}$ by the Knudsen effusion method. J. Phys. III France 1997, 7, 311-319. [CrossRef]

11. Wendlandt, W.W. The thermal properties of inorganic compounds. I. Some mercury (I) and (II) compounds. Thermochim. Acta 1974, 10, 101-107. [CrossRef]

12. Nagayama, K.; Takada, T. Direct combination of thermogravimetric analyzer and atomic absorption spectrometer for detection of atomic vapor in thermal analysis. Thermochim. Acta 1989, 156, 11-19. [CrossRef]

13. Amos, H.M.; Jacob, D.J.; Streets, D.G.; Sunderland, E.M. Legacy impacts of all-time anthropogenic emissions on the global mercury cycle. Glob. Biogeochem. Cycles 2013, 27, 410-421. [CrossRef]

14. Song, S.; Selin, N.E.; Soerensen, A.L.; Angot, H.; Artz, R.; Brooks, S.; Brunke, E.-G.; Conley, G.; Dommergue, A.; Ebinghaus, R.; et al. Top-down constraints on atmospheric mercury emissions and implications for global biogeochemical cycling. Atmos. Chem. Phys. 2015, 15, 7103-7125. [CrossRef]

15. Wu, S.; Uddin, M.A.; Nagano, S.; Ozaki, M.; Sasaoka, E. Fundamental study on decomposition characteristics of mercury compounds over solid powder by temperature-programmed decomposition desorption mass spectrometry. Energy Fuels 2011, 25, 144-153. [CrossRef]

16. Zhu, Z.; Zhuo, Y.; Fan, Y.; Wang, Z. Fate of mercury in flue gas desulfurization gypsum determined by temperature programmed decomposition and sequential chemical extraction. J. Environ. Sci. 2016, 43, 169-176. [CrossRef] [PubMed] 
17. Carpi, A.; Petraco, N.D.K.; Cocris, D.; Ho, A.; Heslin, J. Mechanisms of the reduction and emission of $\mathrm{HgCl}_{2}$ from surfaces. In Proceedings of the 238th ACS National Meeting, GEOC-041, Washington, DC, USA, 16-20 August 2009.

18. Mann, E.; Khusial, R.; Carpi, A. Mechanistic investigation of the reduction and volatilization of mercury in soil. In Proceedings of the 251st ACS National Meeting and Exposition, GEOC-92, San Diego, CA, USA, 13-17 March 2016.

19. Schofield, K. Mercury emission control from coal combustion systems: A modified air preheater solution. Combust. Flame 2012, 159, 1741-1747. [CrossRef]

(C) 2016 by the author; licensee MDPI, Basel, Switzerland. This article is an open access article distributed under the terms and conditions of the Creative Commons Attribution (CC-BY) license (http://creativecommons.org/licenses/by/4.0/). 